\title{
Asegurando en la tierra el pasaje al cielo. De los clérigos y de los religiosos portugueses en Lima, 1580- 1640*
}

\author{
Securing on Earth their Passage to Heaven. About Portuguese \\ Clerics and Religious in Lima, 1580-1640
}

GLEYDI SULLÓN BARRETO

CHAM - Centro de Humanidades

Faculdade de Ciências Sociais e Humanas, FCSH

Universidade NOVA de Lisboa

|069-06 I Lisboa (Portugal)

gleydisullon@gmail.com

iD

RECIBIDO: JUNIO DE 202

ACEPTADO: JUNIO DE 202

Resumen: Este artículo analiza la vida social y las actividades económicas de los clérigos y de los religiosos portugueses que se hallaron en Lima en los años de 1580 a |640. El análisis de los vínculos interpersonales, como modelo metodológico aplicado a este estudio, revela el carácter heterogéneo de estos individuos, la pluralidad de sus pertenencias e identificaciones y el alcance de sus relaciones en el espacio local y extra regional. Asimismo, que su condición de clérigos o religiosos no les impidió -a título personal- involucrarse en las actividades económicas del medio e insertarse -en el caso de uno de ellos - en redes comerciales de alcance transoceánico.

Palabras clave: Lima. Siglo XVII. Portugueses. Clérigos. Órdenes religiosas. Vínculos sociales. Redes comerciales.

Abstract: This article analyzes the social life and the economic activities of the Portuguese Clerics and Religious who lived in Lima, between 1580 and 1640. The analysis of interpersonal relationship, like methodologic method applied to this study, reveals the heterogeneous character of these individuals, the plurality of their belongings and identifications, and the scope of their relationship in the local sphere and extra-regional. Likewise, that their Clerics and Religious condition did not prevent them to engage in economic activities of the region, and set in -in the case of one of them - into commercial networks of transoceanic reach.

Keywords: Lima. $17^{\text {th }}$ century. Portuguese. Clerics. Religious orders. Social ties. Commercial networks.

\footnotetext{
* Este trabajo ha sido financiado con fondos nacionales a través de la FCT- Fundação para a Ciência e Tecnologia, I.P., en el ámbito de CEEC Individual- CEECIND/02544//20 I8/CP I564/CT00I2. Agradezco a Ignacio Chuecas, Pilar Latasa y Ruth Rosas por la clarificación de algunos conceptos. A Celia Soto por haberme facilitado el acceso digital a determinadas fuentes documentales. A Igor Knezevic por la revisión del abstract. La versión final de este artículo ha tenido en cuenta las sugerencias y correcciones de los evaluadores anónimos y de los miembros del Consejo de Redacción de Memoria y Civilización, las cuales agradezco.
}

MEMORIA Y CIVILIZACIÓN 24 (202I): 395-422 [I-28] [ISSN: I I39-0I07; ISSN-e: 2254-6367] 
GLEYDI SULLÓN BARRETO

\section{INTRODUCCIÓN}

La historiografía reciente ha permitido trazar -en los últimos años- un perfil más completo de los hombres y las mujeres de Portugal que en tiempos de la Unión Ibérica - y aun antes de 1580 - tomaron la decisión de viajar al Perú y establecerse principalmente en Lima'.

Un rasgo que caracterizó a estos inmigrantes lusos fue su marcada heterogeneidad. En lo económico, se encuentran mercaderes de grueso trato involucrados en el gran comercio de esclavos, pero también bodegueros y mercachifles que movían un capital modesto en el negocio. En lo social, destacan caballeros de los hábitos de Cristo y de Santiago y familiares del Santo Oficio frente a pulperos pardos y esclavas criollas de Lisboa. En lo político - aunque no fue lo frecuente para el caso limeño- hubo gente vinculada al poder como fue el caso de Francisco Barreto, quien contó con el favor del príncipe de Esquilache, su pariente, para ser nombrado general de la Armada de El Callao. Y, desde el punto de vista religioso, si bien, algunos fueron tenidos por sospechosos de judaizar, hubo clérigos seculares adscritos a iglesias parroquiales; novicios y profesos pertenecientes a comunidades conventuales; e incluso laicos que, en su calidad de terciarios, habían optado por vivir según la espiritualidad de determinada orden religiosa. Todos habrían procurado variadas formas de integración en la nueva tierra.

El objetivo de este artículo es analizar - a partir del estudio de casoslos vínculos sociales y las actividades económicas de un pequeño sector de los portugueses limeños que, de una forma u otra, estuvieron vinculados con las instituciones eclesiásticas y religiosas de la ciudad. De manera específica se estudiará el caso de los clérigos seculares adscritos a parroquias y el de los novicios y profesos de órdenes religiosas; todos ellos habrían coincidido en la Ciudad de los Reyes en los años de 1580 a 1640 . Algunos, aunque cumplieron una labor

\footnotetext{
I Para un estudio de los portugueses, en cuanto sospechosos de judaizar, ver Medina, Historia del tribunal, I y II; Lewin, 1958 y 1960; Reparaz, 1976; Vila Vilar, 1979, pp. 147-184; Ventura, 2005. Para un estudio de la Inquisición peruana y el problema de la Gran Complicidad, ver Castañeda Delgado y Hernández Aparicio, 19891995, I y II. Para el caso específico de la confiscación de bienes, resultantes del mismo proceso: Millar, 1983, PP. 27-58; Quiroz Norris, 1986, pp. 237-303. Para una aproximación al problema desde la fuente notarial, Truhan y Paniagua Pérez, 1997, pp. 201-220, aunque en este trabajo se partió de la hipótesis de que el grupo analizado era cristiano nuevo o judaizante. Para el caso específico de Lima colonial, a partir del análisis de los vínculos interpersonales, Sullón Barreto, 2016. En un estudio reciente Chuecas Saldías, 2018, ha abordado el problema de la endogamia familiar e identidades femeninas a partir de la lista de los portugueses procesados en el auto de fe de 1639.
} 


\section{ASEGURANDO EN LA TIERRA EL PASAJE AL CIELO}

pastoral, destacaron también como prósperos mercaderes y generosos benefactores. Es probable que el poder del dinero les hubiere ayudado a disipar cualquier duda y a superar los inconvenientes sobrevenidos a los prohibidos.

Las fuentes documentales, en su mayoría, proceden de la sección notarial del Archivo General de la Nación de Lima, que recoge buena parte de la vida cotidiana de los individuos de la muestra. Aparte, se ha revisado la sección de Santo Oficio del mismo archivo y otros documentos procedentes del Archivo Arzobispal de Lima y del Archivo General de Indias de Sevilla. Fueron, no obstante, los clérigos seculares los que han dejado una mayor huella documental de su paso por la ciudad. Esto debió ser así porque los seculares, a diferencia de los religiosos, vivían fuera de los recintos eclesiásticos $y$, en consecuencia, tuvieron más posibilidades de acudir a un notario².

El espacio de estudio se circunscribe a Lima, una de las ciudades de la América hispana del sur con mayor población portuguesa, por lo menos hasta 1640. Lima era el centro político y económico del virreinato; articulado con la metrópoli a través de Panamá, se constituía en uno de los puntos claves del circuito comercial hacia Cartagena, Quito y Acapulco, por el norte, y hacia Chile, Cusco y Potosí, por el sur, pasando por otras ciudades y puertos intermedios, y llegando incluso a Europa y Asia.

El marco temporal se extiende de 1580 a I640, periodo en el que los portugueses pasaron a ser, desde el punto de vista jurídico, vasallos del monarca español ${ }^{3}$. Pero, cabe anotar que esta nueva situación no modificó su calidad de extranjeros. Así, se les exigió - como a todos los que no estaban incluidos entre los naturales del reino- licencias de paso y cartas de naturaleza para el comercio con las Indias 4 . Asimismo, quedaron comprendidos entre los individuos que debían pagar composición, en caso de que su ingreso al Nuevo Mundo se hubiere realizado sin las licencias exigidas ${ }^{5}$. En la práctica, no serían pocos los portugueses

\footnotetext{
${ }^{2}$ Sobre las posibilidades de la fuente notarial para el conocimiento de las actividades de los clérigos seculares en las sociedades del Antiguo Régimen, ver Candau Chacón, 1998, pp. III-124.

${ }_{3}^{3}$ Para el proceso de unión de coronas ver Bouza, 1987; Valladares, 2008. Para el periodo posterior a la separación y sus consecuencias, Valladares, 1998.

${ }^{4}$ Al respecto, ver Domínguez Ortiz, 1959, pp. 227-231; Herzog, 2006, pp. I45-175. Para el caso de la concesión de naturalezas a los cargadores portugueses en Sevilla (I583-1645) ver Díaz Blanco, 2007, pp. 9I-104. En un reciente estudio Fernández Chaves, 2020, pp. 85- 126 ha puesto de manifiesto la importancia de las relaciones de confianza de los portugueses en las probanzas de naturalización.

${ }^{5}$ La composición fue una vía utilizada por la Corona española para legalizar a los extranjeros que habían pasado a las Indias sin la correspondiente licencia. En vez de mandar su expulsión, el monarca se avino a regularizarlos mediante el pago de cierta cantidad de dinero. Aunque en 1596 la ley mandaba proceder con moderación con los vasallos de la Monarquía, los portugueses no fueron exceptuados de esta medida. Recopilación de Leyes de los reinos de las Indias, lib. IX, tít. XXVII, leyes XIII-XVII, XXIII y XXIV, t. IV, Pp. I4 y I5. En un pequeño tratado escrito a finales de la década de 1620, Lourenço de Mendoça demandará para los portugueses que vivían en la América española su consideración como naturales, $y$ va a denunciar el hecho de que fueran tratados como
} 
que se hallaron de forma irregular, como se evidencia en los padrones de registro de 1642, aunque esta situación no les impidió establecerse en suelo peruano y desarrollar sus actividades con total normalidad ${ }^{6}$.

Desde el punto de vista metodológico, esta investigación combina el enfoque de la microhistoria con el análisis de los vínculos interpersonales. La microhistoria en tanto que parte del estudio de casos específicos ofrece un acercamiento a los comportamientos individuales $\mathrm{y} /$ o colectivos de los protagonistas. El análisis micro se esfuerza por explotar al máximo el potencial explicativo de los casos particulares, que, si bien, se entienden como «irrepetibles y locales», pueden ser ilustrativos de procesos más amplios ${ }^{7}$. Por su parte, el análisis de los vínculos interpersonales procura una aproximación al mundo social y al espacio relacional de los clérigos y de los religiosos lusos. Ayuda a conocer la posición de estos individuos en la serie de relaciones que establecieron y a entender la pluralidad de sus identificaciones y pertenencias ${ }^{8}$.

\section{VIDA EN SOCIEDAD}

\section{I.I. Identificaciones sociales y pertenencias locales}

El 10 de noviembre de 1610, «estando sano sin ninguna lesión ni enfermedad peligrosa», el bachiller Antonio Dias de Rivadeneira, natural de Portalegre, hizo testamento y se mandó enterrar en el monasterio de la Encarnación de Lima. La fundación de tres capellanías en honor a san Antonio, y la designación del licenciado Blas de Torres Orosco, su paisano, como uno de los capellanes de dichas capellanías, sugiere que el testador luso conservó imborrable el recuerdo de su patria ${ }^{9}$. Aunque nacido en Portugal, era hijo de padre español, realidad que lo situaba - desde el punto de vista jurídico - entre los naturales del reino ${ }^{10}$, no obstante, en la expresión de su última voluntad, Rivadeneira se identificó como portugués.

extranjeros y obligados a pagar composición. Al respecto Mendoça, Suplicación; Cardim, 2008, pp. 522-523, 526; Valladares, 2016, pp. III-II7.

${ }^{6}$ Valga como apoyo a esta afirmación los datos recogidos en el padrón de portugueses de 1642 para el corregimiento de Piura. Se registraron, en ese año, 13 portugueses, de los cuales nueve habían ingresado sin licencia, y solo uno pagó composición en 1595. Su situación irregular, sin embargo, no les impidió el cumplimiento de sus actividades en Piura. Puede verse el «Padrón de portugueses afincados en el corregimiento de Piura, 20 de agosto de 1642», Archivo Regional de Piura (en adelante ARP), leg. 5, exp. 63, fol. Ir- 27r.

${ }^{7}$ Man, 2013, pp. 167-173.

${ }^{8}$ Sobre el análisis de los vínculos interpersonales y su aplicación en el campo de la Historia de América ver Ponce y Amadori, 2008, pp. 15-42; Ponce Leiva, 20I I, pp. 21-44; Ciriza-Mendívil, 2017, pp. 509-527.

${ }^{9}$ Testamento de Antonio Dias de Rivadeneira, Nasca, 10 de noviembre de 1610, Archivo General de la Nación de Lima (en adelante AGN), Prot. Not. 18I, Cristóbal de Barrientos (1604-1618), fol. 70Ir-7IOv.

${ }^{10}$ Hevia Bolaños, Labyrintho, lib. I, cap. I, núm. 37, fol. 16. 


\section{ASEGURANDO EN LA TIERRA EL PASAJE AL CIELO}

Este caso evidencia que las clasificaciones de los individuos bajo ciertas categorías, según y cómo lo establecía la ley, o por su pertenencia a determinada red o colectivo socio-profesional, en la práctica no funcionaban. En el periodo analizado, la Ciudad de los Reyes concentró gentes de muy diversa procedencia, naturaleza y origen étnico, en consecuencia, en el plano de la vida cotidiana, la calificación de un individuo por su naturaleza - con fines excluyentes- resultaba irrelevante.

Hasta hace pocos años, la cuestión religiosa fue un tópico que se halló presente en la mayoría de los estudios sobre los portugueses en el Perú, y en cierta forma condicionó la explicación de ciertos comportamientos. Así, se sugirió, por ejemplo, que la conformación de redes de parientes y coterráneos en los negocios les permitía preservar la fidelidad a la ley de Moisés "'; que la posibilidad de hacer testamento o incorporarse a una institución religiosa les alejaba de la sospecha de judaísmo ${ }^{12}$. Es probable que algunos de estos comportamientos -bajo la figura del disimulo- se hallaran presentes en determinados casos, pero habría que pensar que pudo haber portugueses que vivieron con sinceridad su fe cristiana, y que no necesitaron esconder sus identidades, devociones o pertenencias para insertarse en la sociedad, como se explicará a continuación.

De los portugueses que se hallaron en Lima entre I580 y 1640 , el $9,8 \%$ de los casos conocidos se identificó como clérigo o religioso ${ }^{13}$. En su mayoría fueron seculares, y unos pocos habían ingresado a determinadas órdenes: San Francisco, Santo Domingo y la Compañía de Jesús ${ }^{14}$. De los religiosos adscritos a comunidades conventuales se ha encontrado que al menos dos eran sobrinos de clérigos seculares asentados también en Lima, fueron los casos del fraile franciscano Silvestre de Silva, y de fray Luis Correa, sacerdote teólogo del convento de Santo Domingo ${ }^{15}$. Este último era sobrino de clérigo Manuel Correa, mercader de grueso trato.

\footnotetext{
II Ventura, 2005, II.

12 Tejado Fernández, 1950, p. 60; Böhm, 1998, pp. 54-61; Vila Vilar, 1979, p. 174; Truhan y Paniagua Pérez, 1997, pp. 215-218.

${ }^{13}$ Para este estudio se ha considerado a los portugueses que dictaron testamento en Lima entre 1580 y 1640 Ver al respecto Sullón Barreto, 2016, pp. II5-1/8. En la documentación revisada, los que se identificaron como clérigos pertenecían al clero secular; mientras que novicios, profesos, o frailes estaban integrados en determinada orden religiosa.

14 Monumenta Peruana recoge nombres de portugueses (para las últimas décadas del siglo XVI) que fueron admitidos a la Compañía: I, pp. I8I, 445, 5I8; v, pp. 310, 686; VII, Pp. 238, 24I, 243-244, 246, 255-256; VIII, pp. 39, 17I, 440. Aparte, el padre Antonio de la Calancha recoge en su Crónica las virtudes y servicios del fraile portugués Antonio de Monte Arroyo, quien habría gestionado la llegada a Lima del Santo Crucifijo, «retrato del de Burgos», Calancha, Corónica moralizada, Lib. I, cap. XLII, Pp. I63-270, y cap. XLIV, Pp. 276-282.

${ }^{15}$ Codicilo de Manuel Fernandes Nieto, Lima, 21 de octubre de I62I, AGN, Prot. Not. 17I, Agustín de Atencia (I62I-1622), fol. 422r- 422v; Testamento de Manuel Correa, Lima, II de abril de 1623, AGN, Prot. Not. 1740, Diego Sánchez Vadillo (1619-1623), fol. 7|2r-7|2v.
} 
En 1623, fray Luis Correa fue nombrado, en el testamento de su tío sacerdote, primer capellán de una de las capellanías que el susodicho fundó en Lima. La renta a percibir se estimó en 600 pesos anuales, con la obligación de celebrar determinado número de misas y de cumplir con otras cargas litúrgicas. Con esta renta, el religioso debía cubrir sus gastos de alimentación, hábitos y libros, y procurar la asistencia y alimentación de su madre. Es probable, que la elección por la vida eclesiástica se viera estimulada por la posibilidad de obtener algún beneficio económico (servicio de una capellanía, por ejemplo), o que respondiera - como en el caso expuesto- a un proyecto previsto por el patriarca de la familia, y siempre con fines económicos ${ }^{16}$.

Pero, hubo portugueses que no habrían buscado beneficio económico con su ingreso a la vida religiosa, al contrario, o eran prósperos mercaderes o ejercían determinado oficio que les aseguraba su sustento. Así, se ha encontrado, un comerciante $y$, a la vez, aspirante a jesuita, y un novicio franciscano de oficio barbero. El aspirante a jesuita era Juan de Herrera Leite, quien, al mismo tiempo, se desempeñaba como comerciante de productos importados de México y CastiIla ${ }^{17}$. Por su parte, Antonio de Figueredo, novicio franciscano, ejercía el oficio de barbero en la parroquia de Santa Ana ${ }^{18}$. En ambos casos, la función socio-profesional había precedido a la vocación. ¿Qué razones habrían llevado a estos individuos a ingresar en la vida religiosa?

Es probable que esta opción fuera una de las múltiples formas que encontraron los inmigrantes para integrarse en la nueva tierra ${ }^{19}$. Lejos de la patria y de la familia originaria los portugueses limeños van a crear nuevos vínculos y sentido

16 El clérigo Manuel Correa (citado antes) una vez establecido en Lima atrajo a cuatro de sus sobrinos para hacerles partícipes de sus negocios y buena fortuna.

17 Traslado de testamento de Juan de Herrera Leite, ante escribano Joan Bernardo de Quiroz, Lima, 19 de febrero de 163I, Archivo General de Indias de Sevilla (en adelante AGI), Contratación, 537, N.3, R.8, año 1634 , fol. 18v-30v. Es probable que este portugués se hallara en calidad de aspirante dentro de la Compañía, pues al momento de testar aún vivía en la casa de su morada. Conviene anotar que desde I 546 la Compañía de Jesús distinguía entre la primera probación (antes de entrar a convivir en la casa o colegio a obediencia de la Compañía) y la segunda, que era el período de noviciado y que durante dos años preparaba a los votos del bienio (pobreza, castidad) antes de entrar definitivamente en la Compañía al final de sus estudios. La tercera probación se prolongaba por espacio de un año y se orientaba a la consecución del grado de coadjutor espiritual o profeso, una vez consolidada su preparación intelectual. Esto significa que si un aspirante a jesuita no entraba en la tercera probación podía ser simplemente hermano, o lo que sería el equivalente a lego en las demás órdenes religiosas, situación en la que debió hallarse nuestro personaje. Agradezco a Alexandre Coello por esta aclaración.

18 Testamento de Antonio de Figueredo, Lima, 2 de abril de 1616, AGN, Prot. Not. 825, Francisco Hernández (1616), fol. 5IIr-5I3v.

19 Böhm, 1998, p. 54 sugirió que el ingreso a la vida religiosa de algunos portugueses habría obedecido a sus raíces judaicas, por cuanto este estado les daba la oportunidad de satisfacer sus inquietudes intelectuales, estudiar la Biblia y mantener sus antiguas creencias. 
de pertenencia con su entorno cercano: parroquia, cofradía, o iglesia en la que deseaban ser enterrados.

Estos vínculos dependieron de las particulares afecciones e intereses de los individuos, pues en los casos analizados, los portugueses limeños no actuaron de forma corporativa. Antonio de Figueredo, por ejemplo, mostró especial devoción por la imagen de la Soledad, vinculada a los religiosos de San Francisco, y expresó, en el testamento, su deseo de ser enterrado en el convento de esta orden. Herrera Leite, por su parte, admiró la particular forma en que los jesuitas frecuentaban el culto y la adoración al Santísimo Sacramento, realidad que le movió a dejar el grueso de su hacienda a los padres de la Compañía en Lima. El escribano que certificó su muerte, el 27 de febrero de 1631 , declaró haber visto al susodicho «en un ataúd amortajado con el hábito de la Compañía de Jesús, en la sala de la casa de su morada». Lejos de su tierra y con apenas algún recuerdo de los sobrinos que había dejado en Portugal, Leite pidió a los albaceas que su cuerpo fuera llevado a la casa y colegio de la Compañía para ser enterrado allí. Había muerto bajo el carisma de la orden ignaciana y, según su deseo, «como hermano de su sagrada religión».

La integración de los religiosos lusos en órdenes de distinta fundación revela el carácter heterogéneo de este colectivo, pero también que la política de reclutamiento practicada por estas instituciones no fue restrictiva con respecto a los no españoles ${ }^{20}$. Es probable que algunos se hubieren formado en estas tierras (caso de Figueredo y Leite), pero otros habrían pasado a América tras su profesión u ordenación, si fuera el caso ${ }^{21}$. El vínculo con las órdenes les habría aportado una suerte de compañía, lejos de la familia de origen, pero también cierta seguridad de que - al final de sus días - gentes entregadas a la oración estarían rezando por la salvación de su alma.

En cuanto a los clérigos seculares, los hemos hallado entre los medianos y mayores propietarios del colectivo analizado. A diferencia de los religiosos que vivían en comunidad, estos tuvieron mayor libertad de movimiento, acudieron a las escribanías, y se implicaron de manera intensa en la sociedad en la que estaban

${ }^{20}$ Cabe matizar, sin embargo, que sí hubo un debate en torno a la ordenación de indígenas, mestizos y conversos, sustentado -en teoría - en el criterio de la pureza de sangre. Para una aproximación al tema desde la reivindicación criolla dentro de la Compañía de Jesús, Coello de la Rosa, 2008, pp. 37-66.

${ }^{21}$ Uno de los portugueses que pasó a América ya ordenado fue Francisco Gomes, de Lisboa, quien antes de administrar los indios del trapiche de Simón Luis de Cascos en Lima, fue canónigo de la iglesia catedral de Miranda de Duero en Portugal. Gomes habría contado con licencia para pasar a América, y para administrar las personas de los dichos indios. Traslado de testamento de Francisco Gomes, Lima I 3 de octubre de I604, Archivo Arzobispal de Lima (en adelante AAL), Testamentos, leg. II, exp. 8, 73 folios. De acuerdo con la legislación indiana, los clérigos y los religiosos requirieron de licencia real para pasar a América, por cuanto se buscaba saber si los que viajaban «convenían al servicio de Dios y doctrina y enseñanza de los naturales». Recopilación de Leyes de los reinos de las Indias, lib. IX, tít. XXVI, ley XI, t. IV, p. 3. 
insertos. ¿Quiénes eran estos clérigos seculares? ¿Cuál fue su comportamiento en la sociedad? ¿Cómo fueron percibidos por sus contemporáneos?

De los casos conocidos se cuenta con un canónigo de la iglesia catedral de la ciudad de Miranda de Duero; tres sacerdotes capellanes; un sacerdote de misa de la parroquia de Santa Ana, y otro que se había desempeñado como mayordomo en el monasterio de Santa Clara ${ }^{22}$. Singulares fueron, por otro lado, los casos de Antonio Dias de Rivadeneira y Manuel Correa, de quienes se sabe eran clérigos presbíteros, aunque habrían dedicado la mayor parte de su tiempo a actividades de tipo económico ${ }^{23}$, como se anotará en el epígrafe siguiente.

Por su naturaleza procedían de diferentes regiones de Portugal, y en los casos en que los individuos pertenecían al mismo pueblo, se ha encontrado que esta cercanía se conservó también en Lima ${ }^{24}$. Se entiende que la distancia con respecto a la tierra de origen les llevó a confiar en el vecino más próximo, y este era el paisano ${ }^{25}$.

Los clérigos portugueses se movieron por los más variados espacios de la Ciudad de los Reyes, $y$ aunque hubo preferencias por las parroquias de Santa Ana e Iglesia Mayor (como zonas de residencia), sus vínculos se extendieron más allá de Lima. Aparte de la relación establecida con personas de la misma nación, contaron con la cercanía de españoles y criollos -entre ellos, autoridades civiles y eclesiásticas - para el cumplimiento de ciertos negocios y, especialmente, cuando necesitaron nombrar albaceas en los testamentos ${ }^{26}$.

22 Traslado de testamento de Francisco Gomes, Lima, I 3 de octubre de I604, AAL, Testamentos, leg. II, exp. 8, 73 folios; Testamento de Domingo Lopes, Lima, 5 de febrero de 1620, AGN, Prot. Not. 170, Agustín de Atencia (1618-1620), fol. 54v-56v; Testamento de Manuel Fernandes Nieto, Lima, 19 de octubre de 162I, AGN, Prot. Not. I7I, Agustín de Atencia (I62|-|622), fol. 4I4v-4I8r; Testamento de Blas de Torres y Orosco, Lima, 15 de mayo de 1633, AGN, Prot. Not. 183, Cristóbal de Barrientos (1625-1633), fol. 877v$88 \mathrm{Iv}$; Traslado de testamento de Bernardo Paz, Lima, 26 de marzo de I643, AAL, Testamentos, leg. XXIII, exp. 4,46 folios.

23 Testamento de Antonio Dias de Rivadeneira, Nasca, 10 de noviembre de 1610, AGN, Prot. Not. 18I, Cristóbal de Barrientos (1604-1618), fol. 70Ir-710v; Testamento de Manuel Correa, Lima, II de abril de 1623, AGN, Prot. Not. 1740, Diego Sánchez Vadillo (1619-1623), fol. 703r-728r.

${ }^{24}$ Antonio Dias de Rivadaneira y Blas de Torres eran naturales de Portalegre: el primero confiaría en el segundo el servicio de una capellanía. Testamento de Antonio Dias de Rivadeneira, Nasca, 10 de noviembre de 1610, AGN, Prot. Not. 18, fol. 704r.

25 En la documentación revisada, el concepto de paisano, además de indicar pertenencia a la misma tierra, remitía a relaciones de confianza, solidaridad y afecto.

${ }^{26}$ De acuerdo con la documentación, los clérigos lusos tuvieron contacto con distintas personalidades limeñas, así el licenciado Manuel Correa se vinculó con don Juan de Robles, receptor del Santo Oficio, y Alonso de Hita, cónsul de la Universidad de los mercaderes, entre otros. Cuentas sobre trato en Islas Filipinas don Juan de Robles, receptor del Santo Oficio de la Inquisición; Manuel Correa, presbítero, y Alonso de Hita, cónsul de la Universidad de los mercaderes, Lima, 8 de enero de 1620, AGN, Prot. Not. I207, Diego Nieto Maldonado (1620), fol. 73r-75v. 
La población negra y mulata, por otro lado, tuvo una presencia significativa en el $57,14 \%$ de los casos conocidos. Los testamentos recogen mandas de libertad en favor de esclavos, y referencias a servicios y tratos habidos con ellos. Destinados al trabajo doméstico, algunos formaron parte de los bienes de donación que nuestros clérigos hicieron a las personas de su entorno, y a los hospitales, monasterios y conventos de la ciudad ${ }^{27}$, pero en ningún caso se sugiere la existencia de hijos mulatos de estos clérigos. Tal sospecha, sin embargo, parece más evidente en la relación que algunos pocos establecieron con la mujer indígena. Así, el licenciado Bernardo de Paz reconoció en su testamento haber criado a una niña mestiza, Juana de Paz, a quien le dejó en herencia una negra esclava, y algunos bienes personales, como su ropa blanca de vestir, una cuja, un par de colchones, un pabellón y la cama. Esta generosa donación, y el hecho de que esta mestiza llevara el mismo apellido del clérigo, sugiere que él era el padre ${ }^{28}$.

\section{I.2. De su fe cristiana y de sus vínculos con los conversos}

Los clérigos y los religiosos portugueses, de cara al exterior, eran oficialmente cristianos $^{29}$. Las declaraciones de fe en los testamentos muestran sus preferencias y afecciones en el plano espiritual. Se observa una referencia especial a María Inmaculada como la intercesora por excelencia en ese tránsito hacia la muerte $^{30}$. María es, en la mentalidad de los portugueses limeños. la que ruega por los pecadores «a su precioso Hijo», y se la invoca como el recurso más seguro para alcanzar la salvación ${ }^{31}$. Junto a ella se citan otros miembros de la corte del

${ }^{27}$ En 1623 el clérigo Correa mandó la libertad de tres de sus esclavos, pero solo después de que estos hubieren servido, por determinado tiempo en instituciones religiosas de la ciudad. Testamento de Manuel Correa, Lima, II de abril de 1623, AGN, Prot. Not. 1740, Diego Sánchez Vadillo (1619-1623), fol. 7I8v.

28 Traslado de testamento de Bernardo de Paz, Lima, 26 de marzo de 1646, AAL, Testamentos, leg. XXIII, exp. 4, 46 fol. Por lo general, los clérigos no reconocían expresamente la existencia de hijos mestizos, pero sí procuraron asegurarles su futuro.

${ }^{29}$ Su identificación como cristianos se evidencia no solo en la opción por la vida religiosa o eclesiástica, sino también por la invocación y profesión de fe que recogen los testamentos. Aunque la invocación que da inicio al testamento («En el nombre de Dios, amén»), y la profesión de fe (creencia en la Santísima Trinidad «y en todo aquello que tiene, cree y confiesa la santa madre iglesia de Roma») se mantienen como fórmulas invariables, sí hubo un espacio para la expresión de la voluntad: el nombramiento de intercesores, abogados y patronos, es buena prueba de ello. Es esta parte del testamento -invocación y profesión de fe- la que otorga legitimidad de cristiano al individuo, en una sociedad donde la sospecha de judaísmo acusaba especialmente a la gente de Portugal.

30 En los testamentos de portugueses dictados en Lima, las referencias a la Virgen en su advocación de Inmaculada se presentan especialmente a partir de 1619. Esta ciudad había asistido, unos años antes, a dos solemnidades en honor a la Inmaculada, esto a raíz de la declaración papal de 31 de agosto de 1617 en que, si bien no proclamó el dogma de la Inmaculada Concepción, sí permitía a los defensores de este misterio mantener su parecer en público. Latasa, 2017, pp. 90-92.

31 Traslado de testamento de Juan de Herrera Leite, ante escribano Joan Bernardo de Quiroz, Lima, 19 de febrero de I63I, AGI, Contratación, 537, N. 3, R. 8, año 1634, fol. 19r. 
Cielo como los apóstoles Pedro y Pablo, san Jacinto, san Miguel arcángel, y en un solo caso (de 15 conocidos) se menciona a san Antonio como abogado y patrón ${ }^{32}$.

La elección del lugar de sepultura remite al sentido de pertenencia e identificación local ${ }^{33}$; y el rito funerario, a la dignidad y condición social del difunto. Los conventos de San Francisco y Santo Domingo, y la casa de la Compañía de Jesús atrajeron -como lugar de entierro- al $60 \%$ de los casos conocidos. El resto de individuos escogió las iglesias parroquiales (especialmente Santa Ana e Iglesia Mayor), el monasterio de monjas de la Encarnación, y la iglesia del hospital de los sacerdotes de San Pedro. Fueron pocos los individuos que señalaron sepultura propia al interior de la iglesia ${ }^{34}$, la mayoría de religiosos y seculares había dejado tal elección al parecer del prelado o provincial de determinada institución, y a la voluntad del albacea.

En cuanto al acompañamiento del cuerpo el día del funeral, los clérigos y los religiosos lusos establecieron la forma en que debía cumplirse este, que, por el número de acompañantes -en algunos casos-, y por la calidad del difunto -en otros-, debió impresionar a transeúntes y vecinos ${ }^{35}$. En los documentos revisados se observa, salvo ligeras variaciones, tres tipos de acompañamiento. En primer lugar, la cruz alta, cura y sacristán de la parroquia a la que pertenecía el difunto, era, al parecer, el acompañamiento básico ${ }^{36}$.

En segundo lugar, se pidió la presencia de religiosos y seculares. Entre otros, una representación del cabildo de San Pedro, curas de determinada parroquia, clérigos, frailes de cada uno de los conventos de la ciudad, y finalmente, se llamaba a los «acompañados mayores y menores» ${ }^{37}$. Solo en un caso se pidió la presencia de seis sacerdotes pobres, que a costa del testador debían asistir al

32 Testamento de Antonio Dias de Rivadeneira, Nasca, 10 de noviembre de 1610, AGN, Prot. Not. 18I, Cristóbal de Barrientos (1604-1618), fol. 701r-710v.

${ }^{33}$ La elección del lugar de sepultura se entiende como una forma de integración, y manifestación de afecto hacia determinado lugar. En 1610 el padre Antonio Dias de Rivadeneira se mandó enterrar en el monasterio de la Encarnación, y señaló que, si su muerte ocurría fuera de Lima, de todas formas, sus huesos fueran trasladados a este monasterio. AGN, Prot. Not. 18I, Cristóbal de Barrientos (1604-1618), fol. 702r-702v.

${ }^{34}$ Los que señalaron sepultura propia fueron los cofrades que por su condición de hermanos 24 tenían asegurada la capilla de dicha cofradía. También, los que pudieron pagar su entierro en una capilla, y en un solo caso, el clérigo causante invirtió en la compra de su propia capilla. Sobre esto último, ver Testamento de Manuel Correa, Lima, II de abril de 1623, AGN, Prot. Not. 1740, Diego Sánchez Vadillo (1619-1623), fol. $7 \mid 2 r$.

${ }^{35} \mathrm{El} 88,88 \%$ de los casos conocidos dejó señalado en el testamento la forma en que debía cumplirse el funeral.

${ }^{36}$ En algunos casos bastaba este solo acompañamiento, como así lo pidió, en 1633, el licenciado Blas de Torres y Orosco. Testamento de Blas de Torres y Orosco, Lima, I5 de mayo de 1633, AGN, Prot. Not. 183, Cristóbal de Barrientos (1625-1633), fol. 898r.

${ }^{37}$ En el caso que nos ocupa, el número de los «acompañados» mayores fue de dos en todos los casos conocidos; y el de menores varió de 10 a 12. 
funeral, vestidos «de perpetuán, mucetas para luto, manteo, sotana, y sombrero» ${ }^{38}$. Esta especificación de «sacerdotes pobres» para el cortejo fúnebre de uno de los personajes más ricos de la muestra estudiada, resulta significativa.

En efecto, el licenciado Manuel Correa, cuya hacienda se calculó -en 1623 - en poco más de 400.000 pesos, y que destinó alrededor de 70.000 pesos para la realización de obras filantrópicas en favor de casi todas las instituciones religiosas, educativas y sanitarias de la ciudad ${ }^{39}$, había dejado la organización del funeral al parecer de su confesor, con la sola especificación de que asistieran la cruz alta, cura y sacristán de su parroquia (iglesia mayor), y los seis sacerdotes pobres ${ }^{40}$.

El tercer tipo de acompañamiento estuvo conformado por las cofradías ${ }^{41}$. En el caso de los miembros cofrades, estas corporaciones tenían la obligación de acudir al funeral y prestar auxilios espirituales a sus miembros ${ }^{42}$, pero también acompañaron entierros de individuos que no estaban vinculados a cofradía alguna. Cuando esto sucedía, el testador mandaba — por el alquiler de cera, insignia o estandarte- el pago de la limosna acostumbrada. De las cofradías que acudieron al entierro de los clérigos y de los religiosos lusos, se citan: Ánimas, Santísimo Sacramento, Santo Cristo, Soledad, Rosario y Redención de cautivos, pertenecientes a las parroquias de Santa Ana e Iglesia Mayor, y a los conventos de San Francisco, Santo Domingo, y la Merced. Además de la cera e insignia del hospital de los niños huérfanos de Nuestra Señora de Atocha ${ }^{43}$.

38 Testamento de Manuel Correa, Lima, II de abril de 1623, AGN, Prot. Not. 1740, Diego Sánchez Vadillo (1619-1623), fol. 706v.

${ }^{39}$ De los portugueses que testaron en Lima entre 1570 y 1680, el clérigo Manuel Correa se constituyó en el más importante benefactor. Así, aportó la cuota más alta en todas las donaciones que hicieron los portugueses de ese tiempo. Destinó 1000 pesos a las mandas forzosas cuando la mayoría dejó un monto simbólico; su limosna a las cofradías supuso el 9,05\% del total reunido; el 52,26\% de la otorgada a los hospitales; y el $97,49 \%$ de la que se destinó a iglesias y conventos. Creó, aparte, fundaciones perpetuas en Lima y en Portugal. Sullón Barreto, 2016, p. 201.

40 La presencia de los pobres en los entierros no fue común entre los portugueses limeños, pero el hecho de que acompañaran los entierros era una forma de recordar a los vivos el mensaje de Jesús y su opción por los pobres: «porque tuve hambre y me diste de comer, tuve sed y me diste de beber, estaba desnudo y me vestiste; enfermo y me visitaste; en la cárcel y viniste a mí» (Mt. 25: 35-36).

41 De los clérigos que testaron en Lima, el $50 \%$ de los casos conocidos pidió la presencia de la cera e insignia de determinadas cofradías, aunque solo el $40 \%$ era miembro cofrade.

42 Así se estipulaba en los estatutos y constituciones de cada cofradía, aunque no siempre reinó la prontitud en la prestación del servicio a los cofrades, y especialmente cuando se trataba de cumplir con la ayuda material a los deudos. Al respecto, ver Montoya Estrada, 2017, pp. 181-192.

43 En 162I, el clérigo Manuel Fernández Nieto era cofrade de la cofradía de Ánimas de la Iglesia de Santa Ana, pero a su entierro asistieron otras cofradías a las que se les señaló 10 pesos de limosna. Testamento de Manuel Fernandes Nieto, Lima, 19 de octubre de 1621, AGN, Prot. Not. 171, Agustín de Atencia (16211622), fol. 4I5r. 
La moderación habría caracterizado el rito funerario de nuestros personajes, aun entre aquellos que hubieren podido pagar un funeral de gran pompa ${ }^{44}$. En ninguno faltó la cruz alta, cura y sacristán de la parroquia ni la de sacerdotes y religiosos, y uno solo dispuso que su cuerpo fuera llevado al colegio de Santo Toribio, para que desde allí partiera el cortejo fúnebre, «en forma sacerdotal» ${ }^{45}$. Era, este, su último paseo en público, y aunque algunos habían vivido económicamente bien, de cara a la muerte optaron por la sencillez y la interiorización.

Ciertos detalles como las limosnas en favor de personas e instituciones, las mandas de misas y fundaciones perpetuas que señalaron por su ánima, los objetos religiosos que estuvieron en su poder (tabernáculos, crucifijos, imágenes de la Virgen y de santos), y en general, la profesión de fe y la confesión sincera, recogida en los testamentos, de que habían vivido «como hijos obedientes de la santa madre Iglesia católica, romana» ${ }^{46}$, les presenta, ante la sociedad, como legítimos cristianos, en un contexto en el que la sospecha de judaísmo solía asociarse a todo lo portugués.

La población de Lima de las primeras décadas del siglo XVII se caracterizó por su heterogeneidad. Así, lo documenta un testimonio de época cuando afirma que en la Ciudad de los Reyes y en todo el Perú «andan gentes de todos los lugares, ciudades y villas de España», personas venidas de otras naciones de Europa (portugueses, franceses, italianos, alemanes, flamencos, griegos), «gentes de la India y de la China, y otras muchas mezclas y mixturas». Esta diferenciación - de acuerdo con el mismo testigo- era evidente no solo por la diversidad de su procedencia (étnica o geográfica), sino también por su condición (social o económica), y por sus voluntades ${ }^{47}$. Habría que agregar, en ese contexto de diversidad, que los habitantes de Lima podían ser tratados — según las circunstancias y la perspectiva con que se les mirase- como cristianos viejos o cristianos nuevos. Pero, ¿condicionó esta percepción las relaciones establecidas entre los individuos?

\footnotetext{
44 Por lo general, la celebración de las exequias como espectáculo propio de la teatralidad barroca no estuvo determinada por la sola capacidad económica del causante, lo que contaba era la dignidad del individuo, y su cercanía con la elite citadina y con el poder. Una de estas exequias de gran fasto fue la que se hizo -en México- en honor del jurista limeño Feliciano de Vega y Padilla, organizadas por Juan de Palafox, visitador general y virrey de la Nueva España. Latasa, 2010, pp. 23I-254.

45 Traslado de testamento de Bernardo Paz, Lima, 26 de marzo de I643, AAL, Testamentos, leg. XXIII, exp. 4, 46 folios.

46 Testamento de Antonio Dias de Rivadeneira, Nasca, 10 de noviembre de 1610, AGN, Prot. Not. I8, fol.70 Ir$702 r$.

47 Lewin, 1958, pp. 73-74.
} 
Físicamente no había un rasgo que diferenciara al converso del cristiano viejo ${ }^{48}$, y en el colectivo estudiado se ha encontrado que los vínculos y tratos habidos entre paisanos, no se vieron afectados por su supuesta pertenencia a uno u otro grupo. Así, el I5 de mayo de 1633 Blas de Torres y Orosco, natural de Portalegre, nombró por uno de sus albaceas a Manuel Baptista Peres, que, en ese año, era un reconocido mercader de esclavos, y gozaba de cierta ascendencia en todo el ámbito limeño ${ }^{49}$. Vínculos de paisanaje y amistad debieron unir a estos dos personajes porque entonces no se entendería que, un hombre de tan vastos negocios, aceptara cumplir el encargo de albaceazgo de su amigo sacerdote ${ }^{50}$. En retribución por este trabajo, Torres y Orosco le dejó en herencia, entre otros, «una hechura de nuestro Señor Jesucristo», irónico obsequio para este converso portugués, que pocos años después -entre 1635 y 1639 - sería procesado, y condenado, por el tribunal del Santo Oficio, acusado de ser «el principal en la observancia de la ley de Moisés» ${ }^{51}$.

Vínculos como el mencionado entre Torres y Orosco y Baptista Peres no fueron raros en la Lima de las primeras décadas del siglo XVII, $y$ es que tanto los unos como los otros (los cristianos viejos y los cristianos nuevos) se hallaban viviendo en un mismo contexto geográfico y en el mismo tiempo histórico. Algunos años antes, Manuel Correa, por razón de sus abultados negocios, había tratado también con importantes mercaderes de origen converso, entre otros con Garci Mendes de Dueñas, Álvaro Mendes, Tomé Cuaresma, y Rodrigo de Ávila, todos ellos serían procesados y condenados, por la Inquisición en los autos

48 Cuando Dedieu explica los factores que podían llevar a reconocer a los conversos, en la España del siglo XVII, cita, entre otros: la residencia urbana, el trabajo artesanal, el comercio y la clerecía. Aunque respecto a esto último, señala que no debe interpretarse como una tentativa de cambio de imagen, pues el clero era una salida normal para los segundones de las familias pudientes. Dedieu, 1992, PP. 6I-76.

49 Testamento de Blas de Torres y Orosco, Lima, 15 de mayo de 1633, AGN, Prot. Not. I83, Cristóbal de Barrientos (1625-1633), fol. 899r.

50 Los albaceas eran escogidos entre las personas de confianza, pero la aceptación no era obligatoria. Testamento e inventario de los bienes de Antonio Dias, difunto, Lima, 24 de diciembre de 1629, AGN, Prot. Not. 1853, Antonio de Tamayo (1630), fol. 623r.

51 Medina, Historia del tribunal, II, p. 54. Manuel Baptista Peres murió negativo, es decir, que, a pesar de las torturas a las que fue sometido, nunca aceptó haber realizado prácticas judaicas. 
de fe de 1625,1631 y 1639 , respectivamente ${ }^{52}$. El clérigo, que murió el II de abril de 1623, nunca imaginaría el final trágico de sus socios y paisanos ${ }^{53}$.

\section{NEGOCIACIONES SECULARES}

\section{I. Inversiones agrícolas y circuitos comerciales}

Los clérigos lusos y los aspirantes y profesos de las distintas órdenes religiosas tuvieron en el comercio su principal actividad económica ${ }^{54}$, a pesar de que la legislación indiana prohibía a los hombres de la Iglesia «por ser cosa indecente en ellos, de escándalo y mal ejemplo», participar en operaciones mercantiles ${ }^{55}$. Y no solo practicaron el comercio de géneros, algunos diversificaron sus inversiones: compraron bienes raíces, formaron compañías, actuaron como factores, y realizaron préstamos de capital. Destacan entre ellos un propietario de viñedos en Nasca, un arrendatario de tierras agrícolas, un comerciante de productos importados de México y Castilla, y un mercader de esclavos y de vino, era, este último, el típico hombre de negocios que operó desde Lima y creó una extensa red comercial ${ }^{56}$.

El bachiller Antonio Dias de Rivadeneira había comprado dos haciendas de viñas en el Ingenio de Nasca. Probablemente invirtió en la producción de vino, y en su comercialización en el mercado limeño, pero ya para el año de 1610 había transferido estas dos haciendas - mediante cartas de censo- a Gaspar Martín, quien le pagaba un censo anual de 2500 pesos de a nueve reales. Esta renta debió tener un carácter perpetuo, por cuanto Dias de Rivadeneira la señaló como li-

52 Garci Mendes de Dueñas fue procesado por judaizante, y se suicidó en la cárcel; sus huesos y estatua fueron quemados en el auto de fe de 1625. Álvaro Mendes fue preso por la Inquisición en 1625. Puesto en el tormento confesó ser judío, y después de abjurar fue reconciliado con destierro perpetuo y confiscación de bienes. Tomé Cuaresma fue relajado en persona en el auto de 1639, y Rodrigo de Ávila abjuró de vehementi, y fue condenado a destierro perpetuo de las Indias. Proceso de fe de Garci Mendes de Dueñas, 1625-1627, Archivo Histórico Nacional de Madrid (en adelante AHN) Inquisición, 1648, exp. 16; Montesinos, Auto de la fe; Medina, Historia del tribunal, II, Pp. 27-28, I28-129, 153; Reparaz, 1976, pp. 99-103; Ventura, 2005, I-II, p. 472.

53 ¿Sospechó Correa de la fe de sus compañeros o practicó la tolerancia y aceptación, al margen de las intolerancias institucionales? Es probable que, en la práctica cotidiana, y muy lejos del tribunal del Santo Oficio, los individuos desarrollaran una visión menos excluyente de la sociedad, y reconocieran que la salvación del alma podía darse desde otras confesiones. Al respecto Schwartz, 2010, pp. 191-193.

${ }^{54}$ De los individuos de la muestra, el 54,54\% de los casos conocidos se dedicó a la actividad comercial.

${ }^{55}$ Recopilación de Leyes de los reinos de las Indias, lib. I, tít. XII, leyes II, IV y $\vee$ t. I, Pp. 60-6I. Esta prohibición se recoge también en el Tercer Concilio Limense, acto tercia, cap. 4. Que los eclesiásticos no hagan negocios, Lisi, 1990, p. 167.

${ }^{56}$ No fue raro para periodo estudiado que los hombres de la Iglesia, al margen de su origen o naturaleza, se involucraran en actividades mercantiles y crediticias. Ver al respecto Suárez, 200I, pp. 20-27. 
mosna de las tres capellanías que dejó fundadas en el monasterio de la Encarnación de $\mathrm{Lima}^{57}$. La adquisición de bienes raíces era una forma de inversión de capital, ya que al ser puestos a censo, o en arrendamiento, aseguraba a los propietarios la percepción de una renta para su sustento ${ }^{58}$; $y$ a su muerte, la posibilidad de prolongar el recuerdo de su nombre con el mantenimiento de obras filantrópicas ${ }^{59}$.

Otro portugués involucrado en la producción agrícola fue Manuel Fernandes Nieto, quien, en compañía de Antonio Rodríguez, su casero, tenía arrendada «una chácara de sembradura de trigo y otras cosas». Es probable que los socios hubieren arrendado solo la tierra, pues consta en los documentos que el portugués tenía, por bienes suyos, esclavos, bestias de carga, y otros implementos anejos a la tierra y su labor. La compañía, por lo general, se constituía con gente de confianza, y con el fin de minimizar los riesgos del capital invertido. En el caso referido, la sociedad no se formalizó ante notario, se había basado en la confianza ${ }^{60}$; y la producción y comercialización fue a pequeña escala, pues en I62I, el clérigo luso tenía por cobrar apenas 576 pesos de a ocho reales procedentes de la venta de 96 fanegas de este grano ${ }^{61}$.

En los dos casos expuestos se observa que los clérigos portugueses eran personas versátiles, no limitaron su espacio de actuación a Lima. Los contactos de Antonio Dias de Rivadeneira llegaron hasta Huamanga y el valle del Collao en Nasca, y es probable que realizara algún viaje a España ${ }^{62}$. Por su parte, Manuel

57 El censo referido debió ser enfitéutico perpetuo, en el sentido explicado por Martínez López-Cano (1995, PP. 25-29) por cuanto el clérigo luso, al ceder la propiedad, se aseguró el pago de la renta para el sostenimiento de las capellanías que fundó. Y, para mayor garantía, tuvo el cuidado de nombrar por su albacea y patrón de las capellanías al propio Gaspar Martín, es decir, al que debía pagar la renta. Testamento de Antonio Dias de Rivadeneira, Nasca, 10 de noviembre de 16I0, AGN, Prot. Not. 18, fol. 702r-704v.

58 El clérigo Dias de Rivadeneira tenía además tres pares de casas en el centro de Lima, que había comprado del monasterio de la Encarnación. Es probable que las hubiera puesto en arrendamiento, pero ya para I6I0 había vendido una de ellas a Hernando de Antezana. Testamento de Antonio Dias de Rivadeneira, Nasca, 10 de noviembre de 1610, AGN, Prot. Not. 18, fol. 703r; Autos seguidos por doña Mencia de Sosa, abadesa del monasterio de la Encarnación solicitando aprobación de la venta de unas casas de Antonio Dias de Rivadeneira a Hernando de Antezana, AAL, Monasterio de la Encarnación, Lima, I6II, leg. I, exp. I2, 7 fol.

${ }^{59}$ Una forma de prolongar el recuerdo más allá de la muerte, era la fundación de memorias perpetuas. Ver al respecto la siguiente escritura notarial: Nombramiento de dote, el deán de la iglesia catedral Domingo de Almeida en doña Isabel de Aguilera, doncella huérfana y pobre, Lima, II de octubre de 1638, AGN, Prot. Not. 1796, Diego Sánchez Vadillo, 1638, fol. 2074v-2075v.

60 Antonio Rodríguez y su familia formaron parte del entorno cercano del clérigo luso, quien además era padrino de doña Antonia Pérez Peñalosa, sobrina de Rodríguez. Testamento de Manuel Fernandes Nieto, Lima, 19 de octubre de 1621, AGN, Prot. Not. I7I, Agustín de Atencia (162I-1622), fol. 4I7r-4I7v.

${ }^{61}$ Para 1621 el precio de una fanega de trigo se estimó en 6 patacones. Testamento de Manuel Fernandes Nieto, Lima, 19 de octubre de 1621, AGN, Prot. Not. I7I, Agustín de Atencia (1621-1622), fol. 416r.

62 La capacidad de movimiento de este clérigo queda en evidencia al momento de señalar sepultura, y fundar capellanías. Existe también una manda de 2000 pesos para una mestiza de Huamanga. Testamento de Antonio Dias de Rivadeneira, Nasca, 10 de noviembre de 1610, AGN, Prot. Not. 18, fol. 702r, 703v; 708v-709r. 
Fernandes Nieto tenía vínculos en Guayaquil, y en 1621 se encontraba sirviendo - seguramente a través de un tercero- una capellanía de misas en la iglesia del Espíritu Santo en la ciudad de Lagos, en el Algarve de Portugal ${ }^{63}$. Combinaron su trabajo, como propietarios o arrendatarios de tierras, con el préstamo de capital, y se involucraron en la compra y venta de unos pocos y variados géneros de mercadería. Ambos terminarían sus días en Lima, el primero, como ya tenemos dicho, se mandó enterrar en el monasterio de la Encarnación; y el segundo, en la capilla de ánimas de la iglesia de Santa Ana, de donde era parroquiano. Aunque los dos nombraron por heredera su ánima, cuidaron de recompensar y agraciar, con generosas donaciones, a instituciones, y personas de su entorno, se entiende como una forma de retribución a la ciudad que los había acogido, y donde, seguramente, habían creado y acrecentado, sin sospecha alguna, parte de su fortuna.

Aparte de estos clérigos que invirtieron en la producción agrícola, o en la adquisición de bienes inmuebles con fines rentistas, encontramos un individuo ligado al comercio de los textiles de Castilla, se trató del aspirante a jesuita, Juan de Herrera Leite ${ }^{64}$. Aunque centró su actividad económica en Lima, extendió sus vínculos hacia otras plazas del virreinato: Jauja, Potosí y Cusco; e hizo empleos en México, Tierra Firme y Castilla. Es probable que para algunas contrataciones fuera él mismo el que realizara los viajes; $y$ en otras, que contara con factores e intermediarios ${ }^{65}$.

Las importaciones realizadas por este portugués debieron saldarse con plata, pues consta en los documentos que entre 1629 y 1630 había remitido a España - a nombre de Joan de Quesada - tres barras de plata - y «más 3000 pesos»- para que el susodicho «las empleara» en géneros de Castilla. Paralelamente, y casi al mismo tiempo, entregó a Esteban de Castellanos 2800 patacones para la compra de mercaderías en México. Una cantidad menor estuvo dirigida a Tierra Firme, pues en su testamento reconoció una deuda por cobrar a Antonio de los Santos de I500 pesos más sus ganancias «que por mí llevó a Tierra Firme,

63 Manuel Fernandes Nieto declara, en el testamento, que su tío sacerdote Vicente Alvares fundó una capellanía de misas en la iglesia del Espíritu Santo, en la ciudad de Lagos, en el Algarve, y le instituyó a él por capellán. Testamento de Manuel Fernandes Nieto, Lima, 19 de octubre de 1621, AGN, Prot. Not. I7I, Agustín de Atencia (162I-1622), fol. 4I5v.

${ }^{64}$ De acuerdo con Assadourian, 1982, p. II2, el espacio peruano del siglo XVII se caracterizó por su autosuficiencia económica, pero requirió de la importación de textiles importados, de esclavos negros, y de hierro en barra y manufacturado. Herrera Leite tuvo en los textiles de Castilla el producto dominante de comercialización.

65 Actuaron como intermediarios de Herrera Leite: Joan de Quesada, en Castilla; Esteban Castellanos, en México; Antonio de los Santos, en Tierra Firme; y Nicolás Ramírez, en Potosí. Es probable que este portugués hubiere vivido algún tiempo en Sevilla, pues en el testamento dejó una manda para una iglesia de esa ciudad. Traslado de testamento de Juan de Herrera Leite, ante escribano Joan Bernardo de Quiroz, Lima, 19 de febrero de I63I, AGI, Contratación, 537, N.3, R.8, año I634, fol. 20r-2 Iv; 23v-24r. 
el año pasado [de 1630]». Difícilmente el retorno de la inversión, en aquellas plazas extra regionales, era inmediato, pues hasta el 19 de febrero de $|63|$ el mercader luso aún esperaba que llegaran «a salvamento» los dichos empleos de Castilla y de México, y el capital y ganancias de Tierra Firme ${ }^{66}$.

Esta realidad llevó a nuestro portugués a diversificar sus actividades, y a actuar también como prestamista e intermediario. Procuró contactos en las regiones del interior del virreinato, a donde enviaba los excedentes de las mercaderías locales o importadas ${ }^{67}$. Y, aunque, los textiles de Europa fueron los productos dominantes - y los que habrían de reportarle las mayores gananciastraficó también con mercancías de la tierra, y en menor medida, con géneros asiáticos $^{68}$.

Es probable que en Lima hiciera entregas, al por mayor, pues son escasas las deudas menudas que tenía por cobrar, y destaca más bien una a su favor, por un monto de 3575 pesos del mercader Juan López de Rivera ${ }^{69}$. Dispuso de capital propio (barras de plata y pesos en reales) para hacer las inversiones, y aunque no formó parte de grandes consorcios, sí tuvo contactos en cada uno de los lugares a donde llegaron sus negocios.

Coincidió, en Lima, con otros mercaderes lusos dedicados al mismo rubro, con los que creó una pequeña red de coterráneos. Antonio de los Santos fue su intermediario, en Tierra Firme, y se halló presente el día de su muerte. Con Sebastián Delgado debió compartir un mismo círculo de amigos, entre los que se contó a Juan Báez, maestro zapatero, que sería, a la vez, albacea de Herrera y de Delgado. Felipe Paiva, por su parte, concurriría, también, en calidad de albacea, al recojo de los bienes de nuestro personaje. Había dejado entre otros, poco más de 17.000 pesos de a ocho reales, 60 marcos de plata labrada, tres esclavos, trastes de casa, y un almacén de mercaderías importadas.

66 Traslado de testamento de Juan de Herrera Leite, ante escribano Joan Bernardo de Quiroz, Lima, 19 de febrero de I63I, AGI, Contratación, 537, N.3, R.8, año 1634, fol. 22v-24r. De acuerdo con Suárez, la particular configuración del mercado andino y los efectos de la coyuntura atlántica, en el siglo XVII, llevó a los mercaderes limeños a explorar otras rutas y a invertir en aquellas mercancías (como los géneros chinos o productos de la tierra) que por su consumo masivo y por ser más baratos, tenían una salida rápida en el mercado. Suárez, 200I, p. 129.

67 Se conoce por ejemplo que había entregado en Lima «algunas cosas» a Nicolás Ramírez para que, por su cuenta, las negociase en Potosí. Traslado de testamento de Juan de Herrera Leite, ante escribano Joan Bernardo de Quiroz, Lima, 19 de febrero de I63I, AGI, Contratación, 537, N. 3, R. 8, año I634, fol. 23v.

${ }^{68}$ Aparte de las mercaderías de Castilla, se encontraron en los almacenes de Herrera Leite II varas de tafetán de China y una montera de lana de vicuña. Traslado de testamento de Juan de Herrera Leite, ante escribano Joan Bernardo de Quiroz, Lima, 19 de febrero de I63I, AGI, Contratación, 537, N. 3, R. 8, año I634, fol. 36v y $38 \mathrm{v}$.

69 Traslado de testamento de Juan de Herrera Leite, ante escribano Joan Bernardo de Quiroz, Lima, 19 de febrero de I63I, AGI, Contratación, 537, N. 3, R. 8, año 1634, fol. 23r. 
Aunque dispuso que una parte de sus bienes fueran repartidos a hospitales y personas pobres, el grueso de su hacienda se destinó a la realización de misas en favor de su alma. En este sentido, la Iglesia de la Compañía de Jesús se beneficiaría con 5000 pesos de limosna, y con otros 1000 pesos que señaló el causante para la imposición de una vela al Santísimo Sacramento, el Jueves Santo de cada año ${ }^{70}$. El éxito económico que alcanzó, y que destinó a la realización de obras pías, le habría permitido asegurar el pasaje al cielo, y la oportunidad de mostrar su agradecimiento a los padres de la Compañía, que le habían acogido e integrado -en tierra tan extraña - como a un hermano de religión.

\subsection{La red comercial del clérigo Manuel Correa ${ }^{71}$}

Manuel Correa era natural de Oporto, habría llegado al Perú probablemente en las últimas décadas del siglo XVI, por cuanto en I60I era ya un experimentado mercader de grueso trato ${ }^{72}$. Hijo legítimo de Fernán Lopes y Mayor Correa, procedía de una familia numerosa conformada por seis hijos, entre los que se contaban -aparte el susodicho- Felipa Correa, Violanta Correa, Francisco Lopes Correa, Jorge Lopes Correa y Diego Fernandes Correa. Las dos primeras vivían en Lisboa; y los tres últimos eran ya difuntos en 1623, cuando dictó testamento el clérigo. Aunque emigró al Nuevo Mundo, no perdió sus vínculos con Portugal ni con la familia originaria ${ }^{73}$.

En el Perú, supo rodearse de algunos de los sobrinos a quienes probablemente había atraído a estas tierras para hacerles partícipes de los negocios y de su buena fortuna ${ }^{74}$. Así, los vínculos familiares supusieron, para Manuel Correa, un primer nivel de relaciones que le habría aportado una suerte de compañía y afecto, tan necesarios, en una tierra lejana. Debió valorar el vínculo familiar, pues no solo compartió la misma casa con su sobrina Paula de Mendoza, y con su cuñada doña Úrsula de Mendoza, sino que había procurado el matrimonio entre

70 Ibídem, fol. 20r-20v; 27v-28r.

71 Una aproximación biográfica del clérigo Manuel Correa se publicó en Sullón Barreto, 2016, Pp. 142-I46, pero el hallazgo de documentación inédita como el inventario de sus bienes, sus empleos en Manila, y el balance de sus cuentas en Potosí, justifica su inclusión en este trabajo.

72 Según su propia declaración, en ese año, ya tenía trato económico con su sobrino Fernán Lopes Correa, residente en Potosí. Testamento de Manuel Correa, Lima, I I de abril de 1623, AGN, Prot. Not. I740, Diego Sánchez Vadillo (1619-1623), fol. 719v.

73 Las mandas de limosna a sobrinos y otros parientes en Portugal sumaron 13.000 pesos; aparte con otros 6000 pesos fundó una memoria de misas en el hospital de la Misericordia de las ciudades de Lisboa y Oporto. Testamento de Manuel Correa, Lima, II de abril de 1623, AGN, Prot. Not. 1740, Diego Sánchez Vadillo (I619-1623), fol. 709v-7IIr.

74 Entre los sobrinos que le acompañaron en el Perú se cuentan: Fernán Lopes Correa, Álvaro Mendes, Paula de Mendoza y Luis Correa. Testamento de Manuel Correa, Lima, II de abril de 1623, AGN, Prot. Not. I740, Diego Sánchez Vadillo (I6I9-1623), fol. 7IIr-7IIv; 7I2v y 72 Ir. 
dos de sus sobrinos, deseando seguramente que la hacienda heredada por estos no se dispersara, y quedara como un todo unitario en el conjunto del patrimonio familiar ${ }^{75}$.

Manuel Correa era parroquiano de la Iglesia Mayor donde tenía unas casas principales «con sus altos y bajos, en la calle que va de la pililla de San Agustín al convento de Santo Domingo» ${ }^{76}$. Debió ser una casa espaciosa, y con muchos ambientes como se deduce de los bienes muebles, cuadros, objetos de plata labrada, y alhajas que estuvieron en su poder ${ }^{77}$. Uno de esos ambientes habría representado su espacio de trabajo, y donde seguramente, el clérigo, acostumbraba despachar con su administrador y compadre Luis González Velásquez, y con su abogado, el licenciado Acuña de Olivera. Debió recibir, en más de una ocasión, a sus amigos Garci Mendes de Dueñas y Rodrigo de Ávila; a su médico Tomé Cuaresma, a su confesor y confidente Pedro de Loayza, al doctor Juan de la Roca, al general Francisco Barreto, al boticario Pedro Sánchez Ángel, entre otros ${ }^{78}$. En realidad, es larga la lista de personas que tuvieron trato con Correa, lo que sugiere la ascendencia e importancia de este personaje en la vida económica y social de la ciudad.

Manuel Correa se vinculó con casi todas las instituciones de Lima, y ayudó a sostener casas de recogimiento de niñas huérfanas, colegios de estudiantes, noviciados, conventos de monjas, monasterios de religiosos, y hospitales (como el de san Pedro, san Andrés, san Diego, san Lázaro, y el del Espíritu Santo). Contribuyó a la obra o refacción de las iglesias parroquiales, y de aquellas otras vinculadas a las órdenes dominica, franciscana, agustina y mercedaria. No hay una sola manda a los padres de la Compañía ni al hospital de los naturales de santa Ana, pero sí una gruesa donación a la iglesia de Santo Domingo. Es probable que el licenciado Correa hubiere cultivado un especial afecto por los religiosos y la espiritualidad de los dominicos. De hecho, se mandó enterrar en el convento de

75 En efecto, Manuel Correa mandó a su sobrina doña Paula de Mendoza 10000 pesos de a ocho reales en calidad de dote para el matrimonio, y le encargó casara con su primo Fernán Lopes Correa, residente en Potosí, a quien le había cursado la misma proposición. Testamento de Manuel Correa, Lima, I I de abril de 1623, AGN, Prot. Not. 1740, Diego Sánchez Vadillo (1619-1623), fol. 7 IIv.

${ }^{76}$ Venta de unas casas de morada, Juan de Retes al licenciado Manuel Correa, Lima, 27 de julio de I62I, AGN, Prot. Not. 1006, Gregorio López de Salazar (1619-1621), fol. 1267r-1269v.

77 Inventario de bienes del licenciado Manuel Correa, Lima 16 de abril de 1623, AGN, Prot. Not. 1755, Diego Sánchez Vadillo, I623, fol. 3540r-3544r. Se deduce de esta misma información que su casa disponía de zaguán, patios y bodegas.

78 Se observa en el entorno cercano de Correa un pequeño círculo portugués, que bien podría representar, después del familiar, un segundo nivel de relaciones: Francisco Barreto, Tomé Cuaresma, Rodrigo de Ávila y Garci Mendes de Dueñas. Testamento de Manuel Correa, Lima, II de abril de I623, AGN, Prot. Not. I740, Diego Sánchez Vadillo (1619-1623), fol. 715r-716r; 72Iv; Declaración y cesión de Luis González Velásquez al licenciado Manuel Correa, Lima, 10 de abril de 1623, AGN, Prot. Not. I752, Diego Sánchez Vadillo, I623, fol. $929 r-945 v$. 
Santo Domingo, en la capilla de san Jacinto que compró para tal efecto. Nombró por su confesor y confidente al padre Pedro de Loayza; contribuyó con una manda generosa para el sostenimiento del noviciado, y la creación de un colegio para religiosos dominicos; y aseguró - con el servicio de una capellanía- el sustento de su sobrino sacerdote (también dominico) Luis Correa ${ }^{79}$.

Estos vínculos representaron para el licenciado Manuel Correa su mayor inversión, pues al final de sus días dejó por heredera su alma, lo cual significa que su abultada hacienda, que debió superar los 400.000 pesos, estuvo destinada a la realización de obras pías. El costo monetario que suponía el pasaje al cielo, legitimaba, en cierta forma, la realización de sus negocios y la posesión de sus bienes.

El clérigo Manuel Correa fue un activo hombre de negocios y centró su actividad en el comercio de tres productos considerados dominantes para el periodo que nos ocupa: el vino de Pisco, los esclavos de África y los textiles importados de Europa. Desde Lima controlaba la llegada de las importaciones que venían de Tierra Firme, Nueva España, Europa y Asia y, su distribución por el interior del espacio peruano a través de una red de factores, encomenderos y agentes $^{80}$.

Contó, en efecto, con muchos colaboradores. Uno de ellos fue su sobrino Fernán Lopes Correa, quien operando en la villa de Potosí se integraba en los negocios del clérigo en calidad de factor-servidor, es decir, que recibía una remuneración por su trabajo ${ }^{81}$. Al parecer, tenía, el sobrino, negocios propios, pero durante 22 años - de I60I a 1623-mantuvo con el clérigo «trato y correspondencia muy gruesa». El empresario Correa le remitía desde Lima mercaderías de Castilla, México, China y de la tierra para que el sobrino las vendiera en la villa imperial, y le remitiera, de lo procedido, barras de plata y reales ${ }^{82}$. Debió ser

${ }^{79}$ Fray Luis Correa era sacerdote teólogo del convento de Santo Domingo, y fue nombrado en el testamento de su tío, primer capellán de la capellanía que el susodicho fundó en dicho convento. La renta anual a percibir se calculó en 600 pesos. Testamento de Manuel Correa, Lima, II de abril de I623, AGN, Prot. Not. 1740, Diego Sánchez Vadillo (1619-1623), fol. 712v.

80 Para el análisis de las estrategias practicadas, en la Lima del siglo XVII, por los mercaderes de grueso monto, a partir de un estudio de caso, Suárez, 1995, pp. 54-60.

${ }^{81}$ La remuneración a percibir se había fijado en 1500 patacones anuales, pero en los últimos seis años se le aumentaron 300 más. En total, Fernán Lopes Correa recibió por los 22 años de trabajo, 35500 pesos de a ocho reales, aparte de un $5 \%$ de encomienda que llevó por otros negocios particulares. Aprobación por lo albaceas del licenciado Manuel Correa de las cuentas que tomaron en Potosí a Fernán Lopes Correa, Villa de Potosí, 4 de noviembre de 1624, AGN, Prot. Not. 1759, Diego Sánchez Vadillo (1624-1625), fol. I78v.

82 Potosí representó en el siglo XVII un mercado importante de consumo, tanto de productos de la tierra como importados. De las mercaderías que Fernán Lopes Correa benefició en aquella villa se cuentan: sombreros finos, panes de oro de pintores, libros, vino de Pisco, varas de crea de León, y tafetán de China y de Castilla. Parte de la mercadería se saldaba con barras de plata. Aprobación por lo albaceas del licenciado Manuel Correa de las cuentas que tomaron en Potosí a Fernán Lopes Correa, Villa de Potosí, 4 de noviembre de 1624, AGN, Prot. Not. 1759, Diego Sánchez Vadillo (1624-I625), fol. I63r-I8Iv; Testamento de Manuel Correa, Lima, II de abril de 1623, AGN, Prot. Not. 1740, Diego Sánchez Vadillo (1619-1623), fol. 7I7v-720v. 


\section{ASEGURANDO EN LA TIERRA EL PASAJE AL CIELO}

Potosí una plaza importante para el clérigo mercader, si se tiene en cuenta que el valor de las seis partidas que envió, entre los años de 1602 y I623, variaron de 100.000 a 500.000 pesos de a ocho reales ${ }^{83}$.

Por otro lado, tuvo trato, por vía de compañía, con Álvaro Mendes, mercader de vino y de tejidos. Residente en el puerto de Pisco, y dueño de una tienda de mercaderías, Mendes vendía por cuenta de Correa los géneros que este le enviaba desde Lima, y a su vez, desde el puerto de Pisco, proveía de vino, para su comercialización, en los mercados de Lima y Potosí84. Se sabe, por el balance de cuentas hecho por su albacea, que el clérigo Correa tenía invertido en dicho puerto un total de 43.505 pesos de a ocho reales, entendiéndose que 8685 pesos procedían del valor de las mercaderías; y los 34.820 pesos restantes, de ditas y cuentas, pendientes por cobrar en esa plaza ${ }^{85}$.

Otros agentes del clérigo portugués se hallaban situados en Arica, reino de Chile, Nicaragua, Realejo y provincias de México, a donde enviaba desde Lima - o traía desde esas partes - empleos de mercadurías por vía de factoraje o compañía. Fue su agente, en Arica, Pedro de Fonseca, quien se encargaba de vender en ese puerto las partidas de jabón y vino que le eran remitidas desde El Callao y Pisco. Recibía también las mercaderías que debía consignar a Fernán Lopes Correa ${ }^{86}$.

En la ciudad de la Concepción de Chile contó con dos factores: Marco Antonio de Aguilar y Pedro de San Martín, a ellos les fueron entregadas (entre 1620 y 1621) mercaderías por un valor de 7000 pesos de a ocho reales. Actuó en la misma ciudad, como cargador y factor-encomendero, Joan de Esquivel, escribano del navío Nuestra Señora del Carmen, quien por la venta de las mercaderías llevaba la tercia parte de ganancia por su trabajo y encomienda. Se encargaba también de las cobranzas que había de hacer en ese reino, por cuenta del clérigo ${ }^{87}$.

83 El balance final de las cuentas tomadas a Lopes Correa arrojó un monto favorable al clérigo de 337864 pesos y cinco reales. Aprobación por lo albaceas del licenciado Manuel Correa de las cuentas que tomaron en Potosí a Fernán Lopes Correa, Villa de Potosí, 4 de noviembre de 1624, AGN, Prot. Not. I759, Diego Sánchez Vadillo (1624-1625), fol. 179r.

${ }^{84}$ En 162 I Álvaro Mendes remitió a Manuel Correa 342 botijas de vino en dos partidas, y otras al puerto de Arica consignadas a Pedro de Fonseca para ser llevadas a Potosí. Declaración y cesión de Luis González Velásquez al licenciado Manuel Correa, Lima, 10 de abril de 1623, AGN, Prot. Not. 1752, Diego Sánchez Vadillo, 1623, fol. 940v-94Ir.

85 Álvaro Mendes sufriría, en 1631 , destierro y confiscación de bienes, a causa de su judaísmo, en consecuencia, el finiquito de las cuentas de la compañía quedó pendiente. Auto seguido ante el tribunal del Santo Oficio por el fisco de Álvaro Mendes por la compañía que tuvo con Manuel Correa, Lima, 19 de abril de I65I, AGN, soco, leg. 116 , exp. 954.

86 Declaración y cesión de Luis González Velásquez al licenciado Manuel Correa, Lima, 10 de abril de 1623 , AGN, Prot. Not. 1752, Diego Sánchez Vadillo, 1623, fol. 942r.

87 Declaración y cesión de Luis González Velásquez al licenciado Manuel Correa, Lima, 10 de abril de 1623 , 
Su contacto en México fue Clemente de Vadillo, quien recibía las mercaderías, y remitía lo procedido de esos empleos - y barras de plata- a Sevilla, consignado a Ruy Fernandes Pereira. Debió actuar también como factor, en esas provincias, Antonio Salinas, pues el 10 de enero de 1622 recibió, por cuenta del clérigo, poco menos de 4000 pesos para emplearlos, seguramente en mercaderías asiáticas y europeas. Por su parte, Pedro Pablo Valenciano actuaba en Sonsonate y Realejo, y se sabe que en 1620 había remitido a Lima 52 cajones grandes y 12 zurrones de tinta añil, que aún estaban por vender al momento de la muerte del clérigo ${ }^{88}$.

En Tierra Firme operaban tres de sus agentes: Simón Cascos de Quiroz y los hermanos Gerónimo y Antonio Núñez Caldera. El primero llevó, el 12 de mayo de 1622, 6.300 pesos de a ocho reales para su empleo en mercaderías, de lo que resultó - a vuelta de viaje - 12 fardos y un cajón de géneros importados. Los hermanos Núñez Caldera, por su parte, fueron proveedores de esclavos del clérigo mercader, y entre 1621 y 1622 invirtieron, por cuenta de Correa, poco más de 30.000 pesos, en la compra de 50 piezas de esclavos.

Los negocios del clérigo Manuel Correa llegaron también a Sevilla, y tuvo por contacto, en esa ciudad, a su paisano Ruy Fernandes Pereira ${ }^{89}$, quien poco antes de 1623 había consignado, a través de Nicolás de Guadalupe, tres cajones y seis fardos de géneros textiles europeos, entre otros: 117 piezas de puntas blancas de Flandes, cuatro libras y tres cuartas de hilo portugués, 76 varas de tafetán verde, 76 varas y una cuarta de tafetán azul, cinco piezas de pasamanos terciopelados, 48 varas de tavi pardo y blanco de Sevilla, 70 varas de tocas de lino, 44 varas de tavi rosado y morado de Italia, todo lo cual habría importado algo más de 7000 pesos $^{90}$.

Otros intermediarios del clérigo, en las plazas de Tierra Firme y Castilla, fueron Nicolás de Guadalupe y Bernardino de Morales, quienes a diferencia de Fernandes Pereira, realizaron personalmente los viajes a España. El primero, había llevado por encargo de Correa, en 1620, poco más de 5755 pesos ensayados que invirtió en 28 fardos de géneros textiles, y II cajas de medicina. En el caso de Morales, se sabe, por declaración del clérigo, que le había entregado cinco barras

AGN, Prot. Not. 1752, Diego Sánchez Vadillo, 1623, fol. 930r; 94 Ir-94Iv.

88 Ibídem, fol. 935v; Inventario de bienes del licenciado Manuel Correa, Lima 16 de abril de I623, AGN, Prot. Not. 1755, Diego Sánchez Vadillo, 1623, fol. 3549v.

${ }^{89}$ Ruy Fernandes Pereira, natural de Portugal, fue reconocido por vecino de Sevilla, y obtuvo del Consejo de Indias una carta ejecutoria por la que se le autorizaba a tratar y contratar en las Indias «con que lo hiciere con agentes $y$ factores naturales de estos mis reinos y no por vuestra persona» (3-XII-I583). Dicha ejecutoria le fue confirmada en Madrid el 14 de abril de 1609. Ejecutoria de Ruy Fernandes Pereira de su naturaleza, AGI, Contratación, 596B, Naturaleza de extranjeros, n.3, de portugueses, 1609-1753.

90 Inventario de bienes del licenciado Manuel Correa, Lima 16 de abril de 1623, AGN, Prot. Not. 1755, Diego Sánchez Vadillo, 1623, fol. 355 Ir-3553v. 
de plata y 1500 pesos de a ocho reales «para llevar a emplear a los reinos de España» ${ }^{91}$.

El mundo asiático no estuvo ausente de la vida cotidiana y comercial del clérigo Correa. El inventario de sus bienes permite ver que algunos muebles de su casa, prendas de vestir, y ciertos géneros textiles procedían de China, entre otros, dos escritorios de conchas de China, una cama de China con sus cortinas, unos calzones de damasco, una estola, un manípulo y una guarnición de casulla, todos de China; además de 22 varas de holandita de China, 26 varas y media de lienzo de China, nueve varas de tafetán de China, y un pedazo de tafetán de gaza de China ${ }^{92}$.

Manuel Correa debió ser su propio proveedor de los artículos chinos, por cuanto se sabe que en $16 / 2$ había destinado «3000 pesos de a ocho reales y 342 varas de ruan de cofre delgado para las llevar a las dichas islas Filipinas y venderlas, y emplear su procedido en mercaderías ${ }^{93}$. El monto enviado a esta plaza fue modesto si se le compara con el que destinó a Tierra Firme o Castilla, esto tal vez se deba a los bajos precios de los géneros chinos que, a la vez que le suponía una menor inversión de capital, le aseguraba, también, un mayor margen de utilidad.

Margarita Suárez ha reconstruido cuidadosamente la lista de personajes que actuaron como factores en el navío de permiso a México, en el año de 1612 . Uno de estos factores fue Rodrigo de Ayán, quien, hallándose en Lima -en ese año- y de partida para las Islas Filipinas, habría recibido, por cuenta de mercaderes limeños, un total de 17.600 pesos $^{94}$, entre los que debieron contarse 3000 pesos del clérigo Correa; 3200 pesos de Alonso de Hita, cónsul de la Universidad de los mercaderes, y 5000 pesos del licenciado Juan de Robles, receptor del Santo Oficio ${ }^{95}$. En la escritura de recibo otorgada por Ayán, de 10 de diciembre de 1612 , se obligaba «a dar cuenta de los dichos pesos y empleos que de ello procediese», sin embargo, su muerte en Manila no le permitió cumplir con los compromisos asumidos. Frente a esta situación, serían Bartolomé Tenorio, Francisco

91 Inventario de bienes del licenciado Manuel Correa, Lima 16 de abril de 1623, AGN, Prot. Not. 1755, Diego Sánchez Vadillo, 1623, fol. 3548r; Carta de pago y finiquito del licenciado Manuel Correa a Bernardino de Morales, Lima, II de abril de 1623, AGN, Prot. Not. 1752, Diego Sánchez Vadillo, 1623, fol. 947r-949r.

92 Inventario de bienes del licenciado Manuel Correa, Lima 16 de abril de 1623, AGN, Prot. Not. I755, Diego Sánchez Vadillo, 1623, fol.354Ir-3550r.

${ }^{93}$ Cuentas sobre trato en Islas Filipinas don Juan de Robles, receptor del Santo Oficio de la Inquisición; Manuel Correa, presbítero, y Alonso de Hita, cónsul de la Universidad de los mercaderes, Lima, 8 de enero de 1620, AGN, Prot. Not. I207, Diego Nieto Maldonado (I620), fol. 73r-75v.

${ }^{94}$ Suárez, 2015, pp. II2-113.

${ }^{95}$ Cuentas sobre trato en Islas Filipinas don Juan de Robles, receptor del Santo Oficio de la Inquisición»; Manuel Correa, presbítero, y Alonso de Hita, cónsul de la Universidad de los mercaderes, Lima, 8 de enero de 1620 , AGN, Prot. Not. I207, Diego Nieto Maldonado (1620), fol. 73r-75v. 
Donoso, y don Juan de Alvarado Bracamonte, fiscal en la real cancillería de Manila, los que habrían de encargarse de hacer las cobranzas «de los pesos y varas de ruan de cofre que, por cuenta de cada uno de los tres mercaderes había llevado [Ayán] a las dichas islas de Filipinas ${ }^{96}$. Hasta enero de 1620 este asunto seguía pendiente.

Los empleos realizados en las Indias, en España y en Asia fueron verdaderamente gruesos, de ahí que en todos los casos se contara con la presencia de escribanos que certificaran las transacciones mercantiles ${ }^{97}$. Es probable que el clérigo asumiera personalmente la dirección de sus negocios - como se evidencia en las escrituras que firmó-, pero ya para 1619, y hasta 1623, delegó este trabajo en Luis González Velásquez, su compadre, que sería, más tarde, uno de sus albaceas y el tenedor de sus bienes. En esos cuatro años, González Velásquez administró, cobró, vendió y benefició toda la hacienda del clérigo «en su cabeza, y como si fuera verdaderamente suya», y llevó por salario 6000 pesos de a ocho reales ${ }^{98}$.

Lima representó para el empresario Correa no solo su centro de operaciones, sino también uno de los mercados más importantes de consumo ${ }^{99}$. Fue distribuidor mayorista de géneros importados de Europa, México y Asia, a través de una tienda propia en la calle de los Mercaderes ${ }^{100}$. En 1623 tenía por cobrar solo en Lima algo más de 16.000 pesos de a ocho reales, procedentes de mercaderías que había dado al crédito, y de préstamos de capital. Aunque traficó principalmente con vino, esclavos y ropa importada, lo hizo también -en menor medida - con jabón, trigo, cobre, carbón, medicinas, y libros.

Fue propietario de la tercera parte del navío San Juan Evangelista que compró en compañía de Luis Simón de Losa y Luis Vaes Carmina. Esta inversión, que se hizo en cabeza del doctor Sebastián de Alcocer, le costó, al clérigo, 6200 patacones que pagó al contado ${ }^{10}$. Se asoció con Jacinto Pacheco y el licenciado Pedro de Vega San Martín para la explotación de cobre en las minas de Rinconada

\footnotetext{
${ }^{96}$ Ibídem, fol. 74r.

97 Sullón Barreto, 2016, p. 45.

98 Testamento de Manuel Correa, Lima, II de abril de 1623, AGN, Prot. Not. 1740, Diego Sánchez Vadillo (1619-1623), fol. 719r-719v.

99 El otro mercado importante, para el clérigo luso, era Potosí.

100 La descripción de la ropa de su tienda y trastienda ocupa varios folios de su inventario en Inventario de bienes del licenciado Manuel Correa, Lima 16 de abril de 1623, AGN, Prot. Not. 1755, Diego Sánchez Vadillo, I623, fol. 3555r-3562v.

101 Dicho navío cumplía la ruta entre los puertos de El Callao y Arica, y transportaba mercadería de sus propietarios. Testamento de Manuel Correa, Lima, II de abril de 1623, AGN, Prot. Not. 1740, Diego Sánchez Vadillo (1619-1623), fol. 7I7v.
} 
de Late, pero importó, asimismo, este metal desde Chile. Al momento de su muerte quedaron por vender 16 quintales, tres arrobas y 16 libras de cobre ${ }^{102}$.

Manuel Correa tuvo a su disposición bodegas propias en el puerto de El Callao para el almacenamiento de vino y cobre. En la calle de los Mercaderes tenía una trastienda que servía de depósito de los textiles importados. Y en su casa, unos cuatro o cinco aposentillos y aposentos donde guardaba botijas de vino añejo, botijuelas de miel de Castilla y de Nicaragua, cajones de clavazón, palos de alfarjía de Chile, cajones de acero, sillas de Guayaquil por armar, montones de cobre por labrar, y rejas de arar, entre otros ${ }^{103}$. Se benefició, por otro lado, de los arrendamientos de sus casas, y de los jornales de esclavos y bestias de carga que daba en alquiler.

Manuel Correa representó al típico hombre de negocios que se involucró en las más variadas actividades económicas. Establecido en Lima asumió el control de todas las operaciones mercantiles, y contó con la colaboración de agentes y factores en los principales centros de producción y en los mercados de consumo. Invirtió buena parte de su dinero en las plazas de Lima, Potosí, México, Tierra Firme, España y Filipinas, formó compañías, otorgó préstamos de capital, instaló tienda propia en la calle de los Mercaderes, e invirtió en la explotación de una mina de cobre. Como fiador, lastó y pagó deudas superiores a los 3000 pesos, de Camilo Bonfante y del general Francisco Barreto, pero se contaron también, a su favor, deudas menudas de 20 y 30 pesos de viudas, curas, escribanos, boticarios que habían acudido a él, con la garantía de una prenda. El recuerdo de su nombre se prolongaría en el tiempo gracias a la fundación de memorias perpetuas que señaló tanto en Lima como en Lisboa y Oporto.

\section{CONSIDERACIONES FINALES}

Los vínculos con las instituciones de la Iglesia representaron una forma de integración en el ámbito local limeño y, al mismo tiempo, les permitió legitimar - de cara al exterior - su condición de cristianos. Si bien, en el contexto estudiado, los portugueses fueron identificados - en su mayoría - como judaizantes, hubo también cristianos auténticos - como los casos expuestos- que procuraron la salvación del alma desde el mensaje de Cristo. El contenido y la naturaleza

102 En las primeras décadas del siglo XVII, el quintal de cobre se cotizó en 20 patacones. Declaración y cesión de Luis González Velásquez al licenciado Manuel Correa, Lima, 10 de abril de 1623, AGN, Prot. Not. 1752, Diego Sánchez Vadillo, 1623, fol. 937r.

103 Declaración y cesión de Luis González Velásquez al licenciado Manuel Correa, Lima, 10 de abril de 1623 , AGN, Prot. Not. 1752, Diego Sánchez Vadillo, 1623, fol. 937r y 940; Inventario de bienes del licenciado Manuel Correa, Lima 16 de abril de 1623, AGN, Prot. Not. 1755, Diego Sánchez Vadillo, 1623, fol. 3549r$3549 \mathrm{v}$. 
de los vínculos que establecieron nuestros clérigos y religiosos con otros individuos, que fueron tiempo después procesados por su supuesto judaísmo, evidencia que, en el terreno de la vida cotidiana, y lejos del tribunal del Santo Oficio, se practicó la tolerancia y la aceptación. Muy ilustrativo es, al respecto, el caso del clérigo Manuel Correa para quien la amistad, el paisanaje y los negocios se antepusieron a criterios puramente religiosos.

En lo económico, los clérigos y los religiosos lusos se implicaron en negociaciones de todo tipo. Realizaron inversiones agrícolas, actuaron como prestamistas, rentabilizaron sus propiedades inmuebles con la imposición y percepción de censos, y practicaron el comercio a mediana y a gran escala. El poder del dinero - que les permitió la realización de obras pías- les ayudó a disipar cualquier duda en materia de fe (si la hubo), y justificó — de cara a la ley- las negociaciones seculares y la adquisición de propiedad.

\section{BibliografíA}

Assadourian, Carlos Sempat, El sistema de la economía colonial. Mercado interno, regiones y espacio económico, Lima, Instituto de Estudios Peruanos, 1982.

Böhm, Günter, «Los “portugueses” en el Nuevo Mundo», Cuaderno Judaico, 23, 1998 pp. 4I-65.

Bouza, Fernando, Portugal en la Monarquía Hispánica (I580-I640). Felipe II, las cortes de Tomar y la génesis del Portugal católico, Madrid, Editorial de la Universidad Complutense, 1987.

Calancha, Antonio de la, Corónica moralizada del Orden de San Agustín, en el Perú con sucesos ejemplares en esta Monarquía, Barcelona, Pedro Lacavallería, 1638.

Candau Chacón, María Luisa, «Las formas de vida eclesiástica y las fuentes notariales», en En torno a la documentación notarial y a la historia, ed. Pilar Ostos Salcedo y María Luisa Pardo Rodríguez, Sevilla, llustre Colegio Notarial de Sevilla, 1998, pp. II I-I24.

Cardim, Pedro, «"Todos los que no son de Castilla son yguales”. El estatuto de Portugal en la Monarquía española en el tiempo de Olivares”», Pedralbes, 28, 2008, pp. 521-552.

Castañeda Delgado, Paulino y Pilar Hernández Aparicio, La Inquisición de Lima, Madrid, Deimos, 1989-1998, 3 volúmenes.

Chuecas Saldías, Ignacio, «Hijas de la nación portuguesa. Endogamia e identidades femeninas en las familias de condenados como judaizantes (Lima, 1639)», Andes, Antropología e Historia, I, 29, 20 I8, pp. I-36.

Ciriza-Mendívil, Carlos D., «"Por decir ser yndia”: las difusas fronteras del mestizaje en la ciudad de Quito (siglo XVII)», Colonial Latin American Review, 26, 4, 2017, pp. 509-527.

Coello de la Rosa, Alexandre, «De mestizos y criollos en la Compañía de Jesús (Perú, siglos XVI-XVII)», Revista de Indias, LXVIII, 243, 2008, pP. 37-66.

Dedieu, Jean Pierre, «¿Pecado original o pecado social? Reflexiones en torno a la constitución y a la definición del grupo judeo-converso en Castilla», Manuscrits, 10, 1992, pp. 61-76.

Díaz Blanco, José Manuel, «La Corona y los cargadores a Indias portugueses de Sevilla (I583-I645)», en Iberismo. Las relaciones entre España y Portugal. Historia y tiempo actual y otros estudios sobre Extremadura, coord. F. Lorenzana de la Puente y F. J. Mateos Ascacíbar, Llerena, Sociedad Extremeña de Historia, 2007, pp. 91-104.

Domínguez Ortiz, Antonio, «La concesión de "naturalezas para comerciar en Indias" durante el siglo XVII», Revista de Indias, vol. XIX/76, 1959, Pp. 227-239.

Fernández Chaves, Manuel F., «Comunidad, individuo y estrategias de representación: los mercaderes portugueses y la negociación de su identidad política y económica en Sevilla (I556-1600)», Magallánica, Revista de Historia Moderna, 7, 13, 2020, pp. 85-126.

Hevia Bolaños, Juan de, Labyrintho de comercio terrestre y naval donde breve y compendiosamente se trata de la mercancía y contratación de tierra y mar, Lima, por Francisco del Canto, 1617.

Herzog, Tamar, Vecinos y extranjeros: hacerse español en la Edad Moderna, Madrid, Alianza Editorial, 2006. 


\section{ASEGURANDO EN LA TIERRA EL PASAJE AL CIELO}

Latasa, Pilar, «Teatralidad fúnebre novohispana: exequias en honor de Feliciano de Vega organizadas por Juan de Palafoz (I642)», en Varia palafoxiana. Doce estudios en torno a don Juan de Palafox y Mendoza, ed. Ricardo Fernández Gracia, 2010, pp. 231-254.

Latasa, Pilar, «Lima festeja la Inmaculada (I656): texto criollo y poderes urbanos», Histórica, XLI, 2, 20I7, PP. 89-108.

Lewin, Boleslao (ed.), Descripción del Virreinato del Perú. Crónica inédita de comienzos del siglo XVII, Rosario, Universidad Nacional del Litoral, Facultad de Filosofía, Letras y Ciencias de la Educación, 1958.

Lisi, Francesco Leonardo, El Tercer Concilio Limense y la aculturación de indígenas sudamericanos, Salamanca, Ediciones Universidad de Salamanca, 1990.

Man, Ronen, «La microhistoria como referente teórico metodológico. Un recorrido por sus vertientes y debates conceptuales», Historia Actual Online, 30, 2013, pp. I67-I73.

Martínez López-Cano, María del Pilar, El crédito a largo plazo en el siglo XVI. Ciudad de México (I550-1620), México, Universidad Nacional Autónoma de México, 1995.

Medina, José Toribio, Historia del Tribunal del Santo Oficio de la Inquisición de Lima (I 569-1 820), Santiago de Chile, Imprenta Gutenberg, 1887.

Mendoça, Lorenço de, Suplicación a su Majestad Católica del Rey nuestro señor, que Dios guarde, ante sus Reales Consejos de Portugal y de las Indias, en defensa de los portugueses, Madrid, s. n., 1630.

Millar, René, «Las confiscaciones de la Inquisición de Lima a los comerciantes de origen judío-portugués de "la gran complicidad" de I635॥, Revista de Indias, XLIII/I7I, I983, pp. 27-58.

Montesinos, Fernando, Auto de la fe celebrado en Lima, a 23 de enero de I639, Madrid, Imprenta del Reino, 1640.

Montoya Estrada, Kelly E., «Cartas de hermandad en la cofradía de Nuestra Señora de la Soledad: ¿Salvaré mi cuerpo o solo mi alma?», en Cofradías en el Perú y otros ámbitos del mundo hispánico (Siglos XVI-XIX), comp. David Fernández Villanova, Diego Lévano Medina y Kelly E. Montoya Estrada, Lima, Conferencia Episcopal Peruana, Comisión Episcopal de Liturgia del Perú, 2017, pp. I8I-192.

Monumenta Peruana, ed. Antonio de Egaña y Enrique Fernández, Roma, Monumenta Historica Soc. lesu, $1954-$ 1986, 8 vols.

Ponce Leiva, Pilar, «“Por el mucho amor que les he tenido...”. Sensibilidades y Dinámicas Sociales en Quito a mediados del siglo XVII», Fronteras y sensibilidades en las Américas, coord. Salvador Bernabéu y Frédérique Langue, Madrid, 20I I, pp. 2I-44.

Ponce Leiva, Pilar y Arrigo Amadori, «Redes sociales y ejercicio del poder en la América Hispana: consideraciones teóricas y propuestas de análisis», Revista Complutense de Historia de América, 34, 2008, Pp. I542.

Quiroz Norris, Alfonso, «La expropiación inquisitorial de cristianos nuevos portugueses en Los Reyes, Cartagena y México, I635-1649ı, Histórica, X/2, 1986, pp. 237-303.

Recopilación de Leyes de los reinos de las Indias, Madrid, Boix, I84I.

Reparaz, Gonzalo, Os portugueses no Vice-Reinado do Perú (Séculos XVI e XVII), Lisboa, Instituto de Alta Cultura, 1976.

Schwartz, Stuart B., Cada uno en su ley. Salvación y tolerancia religiosa en el Atlántico ibérico, Madrid, Ediciones Akal, 2010.

Suárez, Margarita, Comercio y fraude en el Perú colonial. Las estrategias mercantiles de un banquero, Lima, Instituto de Estudios Peruanos/ Banco Central de Reserva del Perú, 1995.

Suárez, Margarita, Desafios transatlánticos: Mercaderes, banqueros y el Estado en el Perú virreinal, I600-1700, Lima, Institut français d'études andines, $200 \mathrm{I}$.

Suárez, Margarita, «Sedas, rasos y damascos: Lima y el cierre del comercio triangular con México y Manila en la primera mitad del siglo XVII», América Latina en la Historia Económica, 2, 20I5, Pp. I0I-I34.

Sullón Barreto, Gleydi, Extranjeros integrados. Portugueses en la Lima virreinal, I570-1680, Madrid, Consejo Superior de Investigaciones Científicas, 2016.

Tejado Fernández Manuel, «Un foco de judaísmo en Cartagena de Indias durante el seiscientos», Bulletin Hispanique, 52, I-2, 1950. pp. 55-72;

Truhan, Deborah L. y Jesús Paniagua Pérez, «Los portugueses en América. La ciudad de Cuenca del Perú (I5801640)», Revista de Ciencias Históricas, XII, 1997, pp. 201-220.

Valladares, Rafael, La rebelión de Portugal. Guerra, conflicto y poderes en la Monarquía Hispánica (I640-1680), Valladolid, Consejería de Educación y Cultura, 1998.

Valladares, Rafael, La conquista de Lisboa. Violencia militar y comunidad política en Portugal, 1578-/583, Madrid, Marcial Pons, 2008. 


\section{GLEYDI SULLÓN BARRETO}

Valladares, Rafael, «Poliarquía de mercaderes. Castilla y la presencia comercial portuguesa en la América española, I595-1645», en Valladares, Rafael, «Por toda la tierra». España y Portugal: globalización y ruptura (I580-I 700), Lisboa, CHAM, 2016, Pp. I05-122.

Ventura, Maria da Graça A. Mateus, Portugueses no Peru ao Tempo da União Ibérica: mobilidade, cumplicidades e vivência, Lisboa, Imprensa Nacional, Casa da Moeda, 2005, 3 vols.

Vila Vilar, Enriqueta, «Extranjeros en Cartagena (I593-1630)», Jahrbuch für Geschichte Lateinamerikas, I6, 1979. pp. 147-184. 